\title{
International Trade Costs and Trade Flows: Evidence from the West African Monetary Zone (WAMZ)
}

\author{
Hassan O. Ozekhome \\ Department of Economics, College of Management \& Social Sciences, Glorious Vision University, Ogwa- Edo State, Nigeria \\ E-mail:hassanozeks1@gmail.com \\ https://riiopenjournals.com/index.php/finance-economics-review/index
}

Doi: https://doi.org/10.38157/finance-economics-review.v2i1.80

Citation: Ozekhome, H.O. (2020). International Trade Costs and Trade Flows: Evidence from the West African Monetary Zone (WAMZ). Finance \& Economics Review, 2(1), 63-76. Doi: https://doi.org/10.38157/finance-economicsreview.v2i1.80

\section{Research Article}

\begin{abstract}
Purpose: The study examines the effect of international trade costs on trade flows in the West African Monetary Zone (WAMZ), a sub-regional economic bloc within the Economic Community of West African States (ECOWAS).

Method: Six member countries of the WAMZ, based on data availability, are examined using panel data estimation technique and the Fully Modified Ordinary Least squares (FMOLS), which is employed to test for the robustness of results, for the sample period of 2006-2018.

Results: The study finds a negative and significant effect of international trade costs on trade flows in the WAMZ sub-region. Time to trade is also found to be negatively and significantly related to trade. Exchange rate, financial development (measured by commercial banks' credit to the private sector), and real GDP growth rate (a measure of growth in annual national incomeleconomic size) have a positive and significant impact on trade in the sub-region. The study further finds evidence that the ease of doing business is positively related to trade in the sub-region, but the impact is weak.

Implications: In the light of the empirical findings, the study recommends that policy measures and strategies to reduce international trade costs and time to trade through simplified and harmonized trade procedures be implemented in the sub-region. Policies to encourage national income growth, rapid development of the financial sector and improved ease of doing business should also be implemented in the zone. These should be supported with sound and stable macroeconomic exchange rate management policies, in order to enhance trade and integration in the sub-region.
\end{abstract}

Keywords: International trade costs, Trade flows, WAMZ, Panel data, West Africa, FMOLS 


\section{Introduction}

International trade costs play vital roles in the facilitation of trade and regional integration (see Hoekman, \& Nicita, 2011; Balistreri, Tarr, \& Yonezawa, 2014). As an important determinant of international trade, exchange, and competition, trade costs are vital not only in influencing the volume and pattern of trade, but its efficiency through the channels of technology, increase economies of scale, and the competitive influence of interaction with foreign firms in markets at home and abroad (Bloch \& Tang, 2004). Trade costs as impediments to international trade encompass all costs that are incidental to trade transactions (other than the marginal cost of producing goods) leading to the delivery of goods and services up to the final consumer. Trade costs can be natural or artificial. Although a number of factors affect international trade, increased focus is placed by the World Bank and World Trade Organization (WTO) on the role of international trade costs.

Natural trade costs are those costs incurred in the course of international trade transactions on account of the geographical spread of countries. They include distance-related costs (transportation costs, cost of trade infrastructure), country-specific or fixed costs and time, as well as costs that are incurred as a result of deliberate or conscious government policy. They include costs imposed by tariff barriers, customs, and behind border costs, like local distribution costs, legal and regulatory costs, foreign exchange costs, contract enforcement costs, and communication costs (Portugal- Perez \& Wilson, 2008, cited in Ozekhome, 2019).

According to the World Bank (2015), high trade transaction costs (import and export) contribute to the poor trade volume and pattern among developing countries, thereby weakening trade and growth. Increased trade transaction cost thus represents trade impediments. Aside from being one of the most important factors affecting trade between/among countries, international trade costs play a significant role in the determination of foreign direct investment, firm outsourcing, the proliferation of regional trade and financial agreements (Jack, Meissner \& Novy, 2008, cited in Ozekhome, 2019). The quest to promote trade in the WMAZ sub-region can therefore, not materialize when there are considerable international trade costs. Thus, significant reductions in international trade costs through trade reforms and trade policy synchronization are necessary ${ }^{1}$ to increase the flow of trade in the sub-region and encourage regional economic integration.

While some studies have investigated the determinants of and dynamics of trade flows in the African region (see Portugal-Perez, \& Wilson, 2008; Njinkeu, Wilson, \& Fosso, 2008), no regional study has investigated the nexus between international trade cost and trade flows in the WAMZ sub-region, particularly when viewed against the backdrop that improved and unhindered trade is a desideratum and key structural element for the push towards economic integration in the zone. Given the fact that regional economic and monetary integration largely evolves from trade links, this study becomes particularly important, as the WAMZ member countries have the objective of attaining full economic and monetary union within the sub-region, through the

\footnotetext{
${ }^{1}$ The WAMZ is a sub-regional economic bloc within the ECOWAS. The member countries are Gambia, Ghana, Guinea, Liberia, Nigeria, and Sierra-Leone. They join together, intending to attain economic and monetary union through the coordination of economic and trade policies.
}

64 Published by Research \& Innovation Initiative, 3112 Jarvis Ave, Warren, MI 48091, USA 
use of single currency that promotes trade and non-trade transactions. With this in view, the objective of this study is to fill the gap in the literature by investigating the effect of international trade costs on trade flows in the WAMZ sub-region.

Accordingly, this study is relevant from the perspective of adducing empirical evidence that could inform policies that would be formulated to enhance intra-African trade. In this regard, the paper addresses issues of policy relevance to the WAMZ and entire ECOWAS sub-region, in light of recent policy discussions to create the enabling environment that would promote trade integration in the region.

Following this introductory section, the rest of the paper is organized as follows. Section 2 provides some stylized facts on international trade transaction costs and trade flows in the ECOWAS (which includes WAMZ) sub-region. Section 3 presents the review of related theoretical and empirical literature which considers key theoretical, empirical, and policy issues associated with international trade costs and trade flows. Section 4 contains the methodology, model specification, and data, while Section 5 presents the empirical results and analysis. The conclusion and policy recommendations are presented in Section 6.

\section{Some Stylized Facts on International Trade Costs and Trade Flows in ECOWAS}

At the sub-regional level, according to the African Competitive Repot (2015), the ECOWAS (including WAMZ) remains by far one of the regions with the highest international trade transaction costs, when compared with other regions of the world, such as East Asia \& Pacific, Europe \& Central Asia, Latin America and the Caribbean, Middle East and North Africa and Organization for Economic Cooperation and Development (OECD) high-income countries, within the period 2006- 2018. Specifically, ECOWAS sub-region's cost to export in 2006, 2008, 2010 and 2012 were USD 1,290, USD 1,455, USD 1,484 and USD 1,488 respectively, compared to a world average of USD 1225, USD 1, 336, USD 1,390 and USD 1,484 in the periods. The corresponding average values for East Asia \& Pacific, Europe and Central Asia, Latin America and Caribbean, Middle East \& North Africa and OECD high income in the period 2006-2012 were USD 831.5, USD 1,423, USD 1,138, USD 1, 028, USD 1, 013 (World Bank, 2015).

At a global level, export and import costs between 2006 and 2012, increased by 19.3\% in nominal terms. A similar upward trend occurred in ECOWAS (which includes the WAMZ sub-region), with export and import costs rising to over $25 \%$. According to the statistics, Sub-Saharan Africa (which includes ECOWAS) has the highest cost to export and import, compared with all other regions and the highest cost to import with the exceptions of Latin America and the Caribbean, based on border compliance, and South Asia, based on documentary compliance (Economic Development in Africa Report, 2019).

In terms of applied tariff rates to intra-regional economic community members, ECOWAS, with $3.8 \%$ has the highest when compared to others (Economic Development in Africa Report, 2019). In addition, customs procedures in terms of documents and time to export have been most burdensome in the region when compared to other trading regions. The combination of these factors translates to high international trade costs, which explain the low volume of trade and regional trade integration in the region. In terms of trade volume, total trade from Africa 
(including ECOWAS) to the rest of the world averaged US\$760 billion in current prices in the period 2015-2017, compared with $\$ 481$ billion from Oceania, \$4,109 billion from Europe, \$5,140 billion from America and \$6,801 billion from Asia (Economic Development in Africa Report, 2019). Intra-ECOWAS trade (which includes the WAMZ) (defined as the average of intraECOWAS exports and imports, was less than 10\% during the period 2006-2017, while comparative figures for other regions were, on the average, higher than $45 \%$.

\section{Literature Review}

\subsection{Brief Theoretical Literature}

In theory, the removal of all distortions and obstructions to trade would lead to efficient and optimal resource allocation and encourage the orientation of trade for greater growth. Trade impeding factors, such as high trade transaction costs tend to cause substantial distortions in optimal resource allocation and trade (Bloch \& Tang, 2004, cited in Ozekhome, 2019). The literature on international trade has shown the high international trade costs have the tendency to reduce trade flows between/among countries. Significant trade costs will not only reduce trade volume and pattern among /between countries but will obstruct the efficient and optimal allocation of resources, reduce the prospect for regional trade and economic integration (Asia Development Bank, 2009; World Bank, 2017).

In view of that, considerable trade transaction costs will reduce trade expansion and cause considerable distortions (Portugal-Perez \& Wilson, 2009; Hoekman \& Nicita, 2011). High international trade costs thus constitute a major impediment to regional trade and integration. The essence of the current global trade negotiations is the simplification of trade processes that will lead to the reduction of trade costs to enable developing countries to optimally benefit from multilateral trade liberalization. Policy measures to significantly reduce international trade cost is, in this context, an integral aspect of trade liberalization. In this wise, greater level of trade can be engendered by trade reforms that introduce policy measures and strategies to harmonize and coordinate trade procedures, particularly custom clearance and other border procedures. Through regional trade agreements/cooperation and policy synchronization, a substantial reduction in international trade costs can encourage greater trade and growth Ozekhome (2019).

\subsection{Empirical Review}

Limao and Venables (2001) examine the link between trade infrastructure in terms of international trade costs and trade flows in Africa. They find that trade costs are significant in explaining trade flows. De (2004) examines the effect of international trade cost on regional trade integration in selected Asian countries. The results show that international trade costs significantly influence trade. Mbabazi, Milner, and Morrissey (2006) examine the nexus between trade openness, trade costs, and growth using evidence from Sub-Saharan African countries. The result shows that high trade cost and poor domestic openness contributes to Sub-Saharan Africa's poor trade and growth performance.

Persson (2007) investigates the role of international trade costs and time delays on trade flows in a sample of countries, drawn from African, Caribbean and Pacific regions that are in discussion 
of economic cooperation with the European Union (EU). Using panel data estimation techniques, he finds that that time delays and high trade costs are inimical to trade. Keane and Feinberg (2007) examine the effect of international trade costs on international trade and exchanges, using a sample of 45 countries. Applying a decomposition method, low trade costs are found to stimulate trade flows.

Njinkeu, Wilson \& Faso (2008) use cross-sectional data to examine the impact of trade reforms, custom environment, port efficiency, regulatory environment, and infrastructure on trade across selected African countries. The findings show that improved service infrastructure and port efficiency are key drivers of intra-African trade.

Behars, Manners, and Nelson (2008) investigate the nexus between international trade costs, trade volume, and growth, using evidence from a sample of industrialized and developing countries. Employing dynamic panel data analysis techniques, he obtained empirical evidence showing that trade costs are negatively related to trade volume.

Using comprehensive trade facilitation measures for 2003 and 2004, Iwanow and Kirkpatrick (2008) employed a mean approach to the measures of 'Doing Business and World Development Indicators'. Estimating a dynamic gravity model that incorporates the indicators, the findings show a positive relationship with trade flows in Africa.

Portugal-Perez and Wilson (2009) examine the impact of international trade costs in terms of barriers and opportunities for trade reforms in Africa. The results show that high international trade costs constitute a significant barrier to trade, while low trade transaction cost represents better trade prospect. They conclude that robust trade and policy reforms were necessary to steer trade in Africa. Teravaninthorn and Raballand (2008) find that high transport costs contribute to poor trade in Africa.

Lall, Wang, and Munthali, (2009) examine the effect of trade costs on trade volume in Malawi. He finds that high transports cost reduce trade and competition. A study conducted by the Asian Development Bank (2009) on the link between trade facilitation, trade cost and trade performance in Asia, shows that efforts to stimulate trade should be hinged on trade reforms that consider a reduction in international trade costs.

A UNECA (2013) study on the impact of transaction trade costs on Africa's trade, using indicators such as document time and cost to export and import, reveal that high transaction trade costs are significant obstacles to the continent's regional integration. The findings by Melo and Tsikata (2014) show that high international trade costs constitute significant challenges to trade and regional integration in Africa, and that, the prospect for economic integration can be enhanced through a considerable reduction in international trade costs.

Jouanjean, Gachassin \& Tel-Velde (2015) examine the prospect for regional integration in SubSaharan Africa and find that a significant reduction in international trade costs through the provision of trade infrastructure increases trade. The evidence points to the substantial border effects on trade costs in the region, with enormous opportunities to increase trade and growth, provided there is a well-improved regional infrastructure.

Ozekhome and Oaikhenan (2020) examine the impact of export trade facilitation (proxy by export transaction cost) (i.e. cost to export) on export performance in the ECOWAS sub-region. 
Using data that covered the sample period 2006- 2017 and several panel data estimation techniques, they find a negative relationship between export trade costs and export performance. On the basis of the findings, the authors recommend the simplification, harmonization, and coordination of trade processes in order to reduce export trade transaction costs and stimulate export in the region.

\section{Methodology}

In this section, we specify an international trade cost- trade flows model, as well as discuss the methodology of the study.

\subsection{Model Specification}

The model for the link between international trade costs and trade flows in the WAMZ countries is captured in the functional model of the following form:

$$
T R A D E_{i t}=f\left(C T_{i t}, \text { Xit }\right)
$$

Where; TRADE is the dependent variable, here, the total volume of recorded trade in the WAMZ; TC is international trade cost (the cost to trade); $i$ represents the number of countries (i. the six WAMZ countries); $\mathrm{t}$ is year fixed specific effect, and $\mathrm{X}$ is a vector of other trade determining variables in line with the trade costs literature. These variables include:

TTT- Time to trade (in number of days)

$\mathrm{EDB}=$ World Bank ease of doing business

FDEV= Financial development

REXR = Real exchange rate in terms of the US Dollar

RGDP- Real gross domestic product (GDP)

Following this, the empirical specification of the model to be estimated is, therefore:

$T R A D E_{i, t}=+\alpha_{1}$ CTi, $\mathrm{t}+\alpha_{2}$ TTTi, $t+\alpha_{3} E D B i, t+\alpha_{4} F D E V i, t+\alpha_{5} E X R i, t+\alpha_{6} R G D P i, t$

$+\epsilon_{i, t} \quad(2)$

$\alpha_{1}-\alpha_{6}$ are parameters to be estimated and $\varepsilon$ is the unobserved error term.

The presumptive expectations with respect to sign are: $\alpha_{1}, \alpha_{2}<0 ; \alpha_{3}, \alpha_{4}, \alpha_{6}>0$.

\subsection{Justification for the Choice of the Variables}

A number of variables influence trade flows in the literature, apart from international trade costs. Time to trade cost is a major determinant of trade flows since as a barrier to trade, a high (low) time to trade will reduce (stimulate) greater trade. Its inclusion in the model, thus, follows the modern trade theory (Nordas, Pinali, \& Grosso, 2006, Ozekhome, 2019). The ease of doing business is a determinant of trade, as it reflects the regulatory and policy framework that influence trade process/procedures. Improved ease of doing business, will, therefore, stimulate greater trade flows, as trade procedures are simplified and made less complex. Financial development (deepening) permits efficient allocation of trade credits and finance (see Bougheas \& Falvey (2010, cited in Ozekhome \& Oaikhenan, 2020). Thus, a well-developed financial system is able to promote a greater level of international trade through the mobilization and channeling of trade credits and finance. The exchange rate is a major determinant of 
international trade. In line with the literature, it facilitates the conversion of different currencies into a common denominator. Thus, a change in the exchange would have a resultant effect on trade between/among countries. Increased annual income (indicated growth rate of real GDP) is an important determinant of trade flows, in line with the literature on trade (i.e trade literature), (see Parteka \& Tamberi 2011), since economic growth/increased national incomes suggest greater purchasing power on the part of the citizenry and the country at large. The resultant effect is increased trade flows.

\subsection{Definition of Variables, Measurement, and Sources of Data}

The definitions of the variables in the model, measurement, and the sources of data are provided in Table 1.

Table 1: Definition of Variables, Measurement and Data Sources

\begin{tabular}{|c|c|c|}
\hline Variable & Description/Measurement & Source \\
\hline Trade & $\begin{array}{l}\text { The total volume of recorded trade by the } \\
\text { individual WAMZ member country in US Dollars. }\end{array}$ & $\begin{array}{l}\text { World Development } \\
\text { Indicators (World Bank). } \\
\end{array}$ \\
\hline $\begin{array}{l}\text { International } \\
\text { Trade Costs }\end{array}$ & $\begin{array}{l}\text { International Trade Costs consist of all costs } \\
\text { incidental to trade transactions (other than the } \\
\text { marginal cost of producing goods) leading to the } \\
\text { delivery of goods and services up to the final } \\
\text { consumer. }\end{array}$ & $\begin{array}{l}\text { World Development } \\
\text { Indicators (World Bank). }\end{array}$ \\
\hline Time to Trade & $\begin{array}{l}\text { Time to trade is measured as the number of days } \\
\text { required to get a trade document processed or get a } \\
\text { container/cargo cleared at the border. }\end{array}$ & $\begin{array}{l}\text { World Development } \\
\text { Indicators (World Bank). }\end{array}$ \\
\hline $\begin{array}{l}\text { Financial } \\
\text { Development }\end{array}$ & $\begin{array}{l}\text { Financial sector's credit to the private sector as a } \\
\text { percentage of GDP. }\end{array}$ & $\begin{array}{l}\text { World Development } \\
\text { Indicators (World Bank). }\end{array}$ \\
\hline $\begin{array}{l}\text { Real Exchange } \\
\text { Rate }\end{array}$ & $\begin{array}{l}\text { Exchange rate in terms of the US Dollar corrected } \\
\text { for price changes/inflation }\end{array}$ & $\begin{array}{l}\text { World Development } \\
\text { Indicators (World Bank). } \\
\end{array}$ \\
\hline $\begin{array}{l}\text { Ease of Doing } \\
\text { Business Score } \\
\text { (Index). }\end{array}$ & $\begin{array}{l}\text { Economies are ranked/categorized on the ease of } \\
\text { doing based on composite competitive indicators } \\
\text { from 1-190. A high ease of doing business suggests } \\
\text { less trade regulatory and institutional inhibitions, } \\
\text { while a low rank implies less competitive trade and } \\
\text { business environments. }\end{array}$ & $\begin{array}{l}\text { World Bank Ease of Doing } \\
\text { Business Report. }\end{array}$ \\
\hline Real GDP & $\begin{array}{l}\text { The annual growth rate of real GDP (i.e a measure } \\
\text { of growth in national income) (in percent) }\end{array}$ & $\begin{array}{l}\text { World Development } \\
\text { Indicators (World Bank). }\end{array}$ \\
\hline
\end{tabular}

\subsection{Estimation Technique}

The panel data methodology is adopted in this study. In doing this, the Hausman test is used to select the appropriate model estimation strategy. The study adopts different panel estimatorspooled ordinary least squares (OLS) and panel fixed effect (FE). The latter method builds upon the weakness of the former. While the OLS gives a prima facie kind of evidence, it is however 
not potent enough in the case of panel data because it does not account for time-invariant country-specific effects, and the resulting heterogeneity amongst them. Specifically, the pooled specification assumes that the intercept and slope coefficients are constant across years, and countries. This assumption is too naive, as it does not account for country-specific and year varying effects. The fixed effect controls for the country and year-specific effect, which may have a potential bias on the predictor/ outcome variable (trade flows in this context). In this sense, it eliminates the effect of time-invariant characteristics from the outcome variable, thus allowing the evaluation of the outcome's net effect (Ozekhome, 2017). The Fully Modified Ordinary Least Squares (FMOLS) which corrects for autocorrelation, potential endogeneity of regressors, and reverse causality, is, thereafter, used for robustness check. The latter builds upon the weakness of the former, as it is able to account for considerable heterogeneity to produce asymptotic unbiased, consistent, and efficient estimates (Pedroni, 2000). The estimates are free from endogeneity and simultaneous bias problems, giving considerable heterogeneity among the individual characteristics of the different countries used in the study. Prior to the econometric estimation, the basic characteristics of the variables are examined, using descriptive statistics and panel unit-roots.

\subsection{Data}

The study employs panel data covering the period 2006-2018 on the six (6) WAMZ member countries of the Economic Community of West African States (ECOWAS). The West African Monetary Zone is made up of six countries in the ECOWAS (i.e. West Africa), to attain economic and monetary union through the coordination and harmonization of economic (ie. monetary and fiscal) policies and their convergence. The countries are Gambia, Ghana, Guinea, Liberia, Nigeria, and Sierra-Leone. ECOWAS is a regional grouping of 15 countries that seeks to attain economic integration, industrialization, and development of member countries through the coordination of monetary, fiscal, trade, and financial policies. The study period is dictated by data availability. All the data for this study are obtained from the World Bank's World Development Indicators (WDI).

\section{Results and Analysis}

\subsection{Descriptive Statistics}

Table 2 presents the descriptive statistics of the data on the variables used for the analysis. The average trade to GDP percent for the WAMZ countries is 58.1 percent, with a median value of 59.2 percent. The maximum and minimum values of trade are 70.45 percent and 21.2 percent, respectively. Invariably, total recorded trade flows in the sub-region tend to have assumed a differential pattern among the individual WAMZ member countries during the period. The mean (average) value of international trade transaction cost (the cost to trade) for the sub-region is USD 1,350, with a median value of USD1,362, implying a high international trade cost, that may have slowed total trade flows in the sub-region. The maximum and minimum values are USD 2,035 and USD825, respectively. The corresponding average values for the other variable 
are the time to trade (27days), financial development (18.2 percent), real exchange rate (48.2 USD), and real GDP growth rate (3.96 percent).

Table 2: Descriptive Statistics

\begin{tabular}{|l|l|l|l|l|l|}
\hline & Mean & Median & Max. & Min. & Std. Dev. \\
\hline TRADE & 58.05 & 59.20 & 70.45 & 2123 & 5.82 \\
\hline CT & 1350.2 & 1362.2 & 2035.2 & 825.0 & 22.05 \\
\hline TTT & 27.3 & 26.2 & 63.1 & 11.0 & 3.9 \\
\hline EDB & 83.30 & 82.20 & 96.25 & 8.06 & 4.65 \\
\hline FDEV & 18.20 & 17.85 & 25.45 & 3.80 & 4.20 \\
\hline REXR & 48.20 & 52.20 & 95.20 & 8.60 & 15.2 \\
\hline RGDP & 3.96 & 4.02 & 6.85 & -1.58 & 3.6 \\
\hline
\end{tabular}

Source: Author's computation using Eviews 9

\subsection{Panel Unit Root Test}

As a preliminary and pre-test analysis, the panel unit root test is conducted on the variables to examine their stationarity. The LLC, Fisher-PP, and Fisher-ADF unit root tests are employed. The result of the panel unit root in Table 3 indicates that all the variables are stationary at their levels. Thus, the variables are all of order zero, \{i.e. I(0)\}, and consequently, enter the model directly.

Table: 3: Unit Root Test for Variables in Levels

\begin{tabular}{|l|l|l|l|l|l|l|l|}
\hline Test & TRADE & TC & TTT & EDB & FDEV & REXR & RGDP \\
\hline LLC & $-2.19^{* *}$ & $-2.25^{* *}$ & $-2.16^{* * *}$ & $-2.25^{* *}$ & $-1.86^{*}$ & $-2.10^{* *}$ & $-2.24^{* *}$ \\
\hline $\begin{array}{l}\text { Fisher- } \\
\text { PP }\end{array}$ & $18.30^{*}$ & $26.15^{* *}$ & $50.44^{* * *}$ & $25.20^{* *}$ & $26.30^{* *}$ & $30.33^{* *}$ & $28.50^{* *}$ \\
\hline $\begin{array}{l}\text { Fisher- } \\
\text { ADF }\end{array}$ & $40.22^{* *}$ & $37.90^{* *}$ & $43.26^{* *}$ & $25.43^{*}$ & $45.64^{* *}$ & $29.24^{*}$ & $27.27^{*}$ \\
\hline
\end{tabular}

*** Statistical significance at the $1 \%$ level; ** Statistical significance at the $5 \%$ level

* Statistical significance at the $10 \%$ level

Source: Author's computation using Eviews 9

\subsection{Panel Data Analysis}

As in conventional in case of standard panel data analysis, a choice is made on the appropriate estimation strategy between the random and fixed effects, using the Hausman test. Using this test, the fixed-effect strategy is more appropriate, given a Hausman test statistic of 10.02, with a probability value of 0.03 , which is significant at the 5 percent level, indicating the rejection of the null hypothesis of no biases (i.e. correlation between the error term and independent variables) when the random effect strategy is used. This perfectly makes the fixed effect result in the best 
result. The Pooled OLS and Panel Least Squares (Fixed Effect) results - are reported in Table 4. Using relevant diagnostics, the fixed effect result, is again, preferred over the pooled OLS results. Thus, the fixed effect result is analyzed and interpreted, along with the alternative results from the FMOLS, which is used to test for robustness. The goodness of fit indicated by the coefficient of determination of the panel fixed effect show that over 71 percent of the systematic variations in trade in the WAMZ sub-region are explained by the regressors.

Table 4: Trade and its Explanatory Variables

\begin{tabular}{|c|c|c|c|}
\hline Variables & Pooled OLS & $\begin{array}{l}\text { Panel } \\
\text { (Fixed Effect) }\end{array}$ & FMOLS \\
\hline $\mathrm{C}$ & $\begin{array}{c}0.823 \\
(0.964)\end{array}$ & $\begin{array}{r}0.0172 \\
(1.243)\end{array}$ & \\
\hline $\mathrm{CT}$ & $\begin{array}{l}-1.022^{*} \\
(-1.650)\end{array}$ & $\begin{array}{l}-1.036 \\
(-2.157)^{* *}\end{array}$ & $\begin{array}{l}-1.116 \\
(-2.250)^{* * * *}\end{array}$ \\
\hline TTT & $\begin{array}{l}-0.188 \\
(1.273) \\
\end{array}$ & $\begin{array}{l}-0.240^{*} \\
(1.853) \\
\end{array}$ & $\begin{array}{l}-0.284^{*} \\
(1.921)\end{array}$ \\
\hline EDB & $\begin{array}{c}1.062 \\
(1.208)\end{array}$ & $\begin{array}{l}1.207 \\
(1.502)\end{array}$ & $\begin{array}{l}1.252 \\
(1.604)\end{array}$ \\
\hline FDEV & $\begin{array}{c}0.213^{* *} \\
(2.072)\end{array}$ & $\begin{array}{l}0.236 \\
(2.156)^{* *}\end{array}$ & $\begin{array}{l}0.243 \\
(-2.220)^{* *}\end{array}$ \\
\hline REXR & $\begin{array}{c}0.017 \\
(1.233)\end{array}$ & $\begin{array}{l}0.027^{* *} \\
(2.051)\end{array}$ & $\begin{array}{l}0.035 \\
(2.162)^{* *}\end{array}$ \\
\hline RGDP & $\begin{array}{l}0.248^{* *} \\
(2.172)\end{array}$ & $\begin{array}{l}0.246^{* *} \\
(2.220)\end{array}$ & $\begin{array}{l}0.252^{* *} \\
(2.310)\end{array}$ \\
\hline Hausman Test & & $10.02(0.03)^{* *}$ & \\
\hline \multicolumn{4}{|c|}{ Diagnostic Statistics } \\
\hline $\mathrm{R}^{2}$ & 0.16 & 0.711 & \\
\hline F-statistic & $1.97^{*}$ & $28.05^{* * *}$ & \\
\hline Durbin-Watson & 0.92 & 1.63 & \\
\hline Mean VIF & & 1.62 & \\
\hline $\begin{array}{l}\text { Breusch-Pagan } \\
\text { LM Test }\end{array}$ & & $2.95(0.70)$ & \\
\hline $\begin{array}{l}\text { Long-run } \\
\text { variance }\end{array}$ & & & 0.04 \\
\hline
\end{tabular}

Note:***,**\&**indicate statistical significance at the $1 \%, 5 \%$ \& $10 \%$ levels, respectively; t-ratios are in parenthesis.

This implies the explanatory variables are significant in explaining trade flows in the subregion, making the predictive power of the model good. The F-statistic is highly significant, passing the significance test at the $1 \%$ level; a confirmation of the reliability of the explanatory power of the model, and, validating the hypothesis of a significant linear relationship between 
trade flows and its predictor variables in the WAMZ sub-region. The Durbin Watson statistic of 1.63 for the panel fixed effect results and the long-run variance of 0.04, for the FMOLS show clear absence of autocorrelation in the results, making both estimates, reliably fit for structural and policy analyses.

The coefficient of international trade costs is negative in line with a priori expectation and it is statistically significant at the 5 percent level, in the panel fixed effect and FMOL results. This implies that high international trade cost has a weakening effect on trade flows in the WAMZ sub-region. This finding supports the results of Njinkeu, Wilson, and Fosso (2008), PortugalPerez and Wilson (2009), Hoekman and Nicita (2011), and Ozekhome and Oaikhenan (2020). The coefficient estimate (using the FMOLS results) indicates that a unit increase (decrease) international trade costs will reduce (stimulate) trade within the WAMZ sub-region by about 1.2 .

The coefficient of time to trade is negatively signed with trade and statistically significant at the 10 percent level in both the panel fixed and FMOLS estimations. Invariably, high time to trade in terms of complex custom procedures and other trade clearance processes tend to diminish trade performance in the WAMZ sub-region. The finding supports the findings of Nordas, Pinali, and Grosso (2006). The estimated coefficient shows that a unit rise (decrease) in time to trade will, decrease (increase) trade in the sub-region by about 0.28 .

The coefficient of the ease of doing business, though positively related to trade, is not significant in both the panel fixed and FMOLS results. This implies that although better policy regulations (in terms of macroeconomic and institutional environments) tend to engender greater trade, the impact is weak in the WAMZ sub-region. This finding is due perhaps, to the weak regulatory and institutional environments that have made business and trade processes/procedures complex, thereby reducing the intensity (volume) of trade. This finding supports the results of Iwanow and Kirkpatrick (2008). The coefficient indicates that a unit improvement in the ease of doing business will induce greater trade in the sub-region by 1.3 .

The coefficient of financial development (proxy by domestic credit to the private sector) is positively related to trade, and it is significant at the 5 percent level, both the fixed and FMOL estimations. Thus, trade credits tend to encourage trade in the WAMZ sub-region. The finding corroborates the evidence by Bougheas and Falvey (2010), and is at variance with the findings of Ozekhome and Oaikhenan (2020). The coefficient estimate of the variable indicates that a unit increase in trade credits will, stimulate international trade in the sub-region by 0.24 .

The coefficient of the real exchange rate is positively signed and passes the significance test at the 5 percent level in the panel fixed effect and FMOLS results. Thus, currency devaluation/depreciation engender a higher level of trade in the WAMZ sub-region, since the export commodities from the zone become cheaper in the international market, given favorable demand for the export commodities that are demand elastic. This finding supports the results of Adamu, Ighodaro, and Iyoha (2012). Nevertheless, WAMZ countries are largely primary producing and are yet to achieve meaningful diversification in trade and output composition. The coefficient estimate indicates that a unit percent depreciation in the exchange rate will increase trade in the sub-region by approximately 0.04 percent. The coefficient of the growth 
rate of real GDP (a measure of the increase in annual national income) is positively signed, in line with theoretical expectation, and highly significant for the full estimation. Thus, increased annual income/economic activities encourage greater trade flows in the sub-region. The finding supports the evidence by Parteka and Tamberi (2011). The coefficient indicates that a unit increase in real GDP growth will, on the average, encourage trade in the WAMZ by about 0.25. The post-estimation evidence of the panel fixed effect result leads to the non-rejection of the null hypothesis of no serial cross-sectional dependence and contemporaneous correlations, using the Breusch-Pagan LM test for cross-sectional dependence and contemporaneous correlation (with $\left.\mathrm{Chi}^{2}=2.95(0.70)\right\}$. The mean-variance inflation factor (VIF) of 1.62, shows the absence of multicollinearity in the estimated model. There is, accordingly, no evidence to invalidate the model, as the parameter estimates can be used for policy formulation and implementation.

\subsection{Policy Implications of Findings}

Several important policy implications can be deduced from the empirical findings. First, high international trade transaction cost has a diminishing effect on trade in the WAMZ sub-region. By implication, countries in the sub-region must carry out strategic reforms in trade policy and environment, geared towards the reduction of international trade costs through the simplification, harmonization, modernization, and transparency of trade procedures.

Second, time to trade is negatively related to trade. This finding implies that the greater the time necessary to trade, in terms of time delays in processing trade documents, custom and other border clearance, the lower the trade in the sub-region. Against this backdrop, there is a need to develop strong time to trade -reducing policies and measures through trade cooperation/agreements that will considerably increase trade flows in the sub-region.

Third, financial development is positively related to trade in the sub-region, as it helps in the efficient financial intermediation, mobilization, and channeling of credit to the tradeable sectors of the economy, with the consequence of greater trade in the sub-region. It is, therefore, necessary that strong monetary, regulatory, and supervisory policy/ frameworks be implemented to steer the development of the financial sector towards promoting trade in the sub-region. Fourth, the findings show that a good trade environment brought about by better trade policies, and regulatory and institutional framework encourages trade. The implication is that improvements in the regulatory, policy, and institutional frameworks are needed to steer trade in the WMAZ Sub-region. Fifth, the results indicate that a competitive exchange rate is necessary to trade in the sub-region. Thus, there is a need for the adoption and implementation of sound, stable, and competitive exchange rate macroeconomic policies that will greatly promote trade in the sub-region. Finally, the findings show that national income is an important determinant of trade flows in the WAMZ sub-region. By implication, policies to increase national income growth capacity, particularly through economic diversification should be implemented in the sub-region.

\section{Conclusion}


The study examined the effect of international trade on trade flows in the WAMZ sub-region. Employing panel data estimation techniques, wherein the fixed effect was selected as the appropriate estimation strategy, and the fully modified OLS (FMOLS), which was used to test for robustness, the empirical results reveal that trade costs are negatively and significantly related to trade. Time to trade is also found to be negatively related to trade in the sub-region. Financial development (measured as the private sector to GDP percent), exchange rate and real GDP growth rate are positively and significantly related to trade in the sub-region, while the ease of doing business is positively related to trade, albeit a weak impact, due perhaps, to the poor trade policy, institutional and regulatory environment that tend to reduce trade in the subregion.

Against the foregoing background, strong and result-oriented trade reforms in trade policy that will significantly reduce international trade costs need to be implemented in the sub-region through the simplification, coordination, and harmonization of trade procedures/processes. Besides, strong and competitive exchange rate management policies are imperative to drive trade in the sub-region. Continuous and unrelenting financial sector development policies, through financial sector reforms through supervisory and regulatory monetary policy/framework are important. National income -enhancing policies through economic diversification and increased production are also imperative. Finally, greater ease of doing business policy measures should be adopted through improvements in the political, regulatory, policy, and institutional environments. The combination of these policy measures will significantly trigger trade in the WAMZ sub-region.

\section{Direction for Further Research}

Future researchers should disaggregate international trade costs into its components and the relationship can be examined with trade flows. Expanding the number of countries to SubSaharan Africa would be another future research perspective.

Conflicts of Interest: The author declares no conflict of interest.

\section{REFERENCES}

World Economic Forum (2015). African Competitive Report 2015. World Bank.

Asian Development Bank (2009). Trade facilitation, trade costs, and trade performance in Asia. Working Paper 25.

Behars, P. \& Manners, S. (2008). Trade costs, Trade volume, and Growth. Trade Policy Working Paper N0. 86.

Bloch, H \& Tang, H. K. (20004). Deep determinants of economic growth: institutions, geography, and openness to trade. Progress in Development Studies, 4(3), 245-255.

Bougheas, S. \& Favley, R. (2010). The impact of financial market frictions on trade flows, capital flows, and economic development. Paper Presented at the Conference on Global Financial Crises, University of Nottingham, U.K.

De, P. (2004). Transaction costs as barriers to economic integration in Asia: An empirical exploration'. RIS Discussion Paper No. 77, Research and Information System for Developing Countries, New Delhi.

Economic Development in Africa Report (2019). Geneva, Switzerland; the World Bank.

Hoekman, B. \& Nicita, A. (2011) Trade policy, trade costs, and developing country Trade. World Development 39(12), 2069-2079. [POBS, cross sectional]. 
Iwanow, T. \& Kirkpatrick, C. (2007). Trade facilitation and Manufactured exports: Is Africa different? World Development, 37(6), 1039-1050.

Jacks, E., Missner, C \& Novy, D. (2008). Measuring international trade costs with panel data. Trade Policy Working Paper No. 47.

Jouanjean, M. A., Gachassin, M. \& Tel-Velde, D.W.T. (2015). Regional infrastructure for trade facilitation- on growth and poverty. Department for International Development, UK.

Keane, S. \& Feinberg, K. (2007). Trade costs and international exchange. Journal of Trade and Investment, 24(6), 75-92.

Lall, S.V., Wang, H. \& Munthali, T. (2009). Explaining high transport costs within Malawi - Bad Roads or Lack of Trucking Competition?' Policy Research Working Paper 5133. Washington, DC: World Bank.

Limao, N. \& Venables, A.J. (2001). Infrastructure, geographical disadvantage, transport costs, and trade. World Bank Economic Review, 15, 451-479.

Mbabazi, J., Milner, C. \& Morrissey, O. (2006). Trade openness, trade costs, and growth: Why Sub-Saharan Africa performs poorly. Credit Research Paper, University of Nottingham, N0.06/08.

Melo, J. \& Tsikata, Y. (2014). Regional integration in Africa: Challenges and prospects. Working Paper 2014/037. Helsinki: UNU WIDER.

Njinkeu, D, Wilson, J.S. \& Fosso, B. P. (2008). Intra-African trade constraints: The impact of trade facilitation. World Bank Memo.

Nordas, H., Pinali, E. \& Grosso, M. (2006). Logistics and time as a trade barrier. OECD Trade Policy Working Paper No. 35.

Ozekhome, H. \& Oaikhenan (2020). Export trade facilitation and export performance in ECOWAS Countries: A multi-variant panel data approach (Forth-coming).

Ozekhome, H. (2019). Logistics, Trade facilitation, and economic growth: Evidence from ECOWAS countries. Ph.D. Dissertation Submitted to the Department of Economics and Statistics, University of Benin, Nigeria.

Ozekhome, H. O. (2017). Does money supply growth cause inflation in the WAMZ Countries? West African Journal of Monetary and Economic Integration (WAJMEI), 17(2), 57-90.

Pedroni, P. (2004). Panel cointegration: Asymptotic and finite sample properties of pooled time series tests with an application to the PPP hypothesis. Econometric Theory, 20 (3), 597-623.

Persson, M. (2007). Trade facilitation and the EU-ACP Economic Partnership Agreements: Who has the most gain? Lund University Working Papers, No. 2007.

Portugal-Perez, A. \& Wilson, J.S. (2009). Trade costs in Africa: Barriers and opportunities for reform. Policy Research Working Paper 4619, World Bank.

Teravaninthorn, S. \& Raballand, G. (2008). Transport prices and costs in Africa: A review of the International Corridors. Directions in development infrastructure Paper 46181. Washington, DC: World Bank.

UNECA (2013). Trade facilitation from an African perspective. ECA Documents Publishing and Distribution Unit, Addis Ababa, Ethiopia.

World Bank (2015). Trade and growth indicators. World Bank, Washington DC, World Bank. (c) 2020 by the authors. Licensee Research \& Innovation Initiative, Michigan, USA. This article is an open-access article distributed under the terms and conditions of the Creative Commons Attribution (CC BY) license (http://creativecommons.org/licenses/by/4.0/). 